
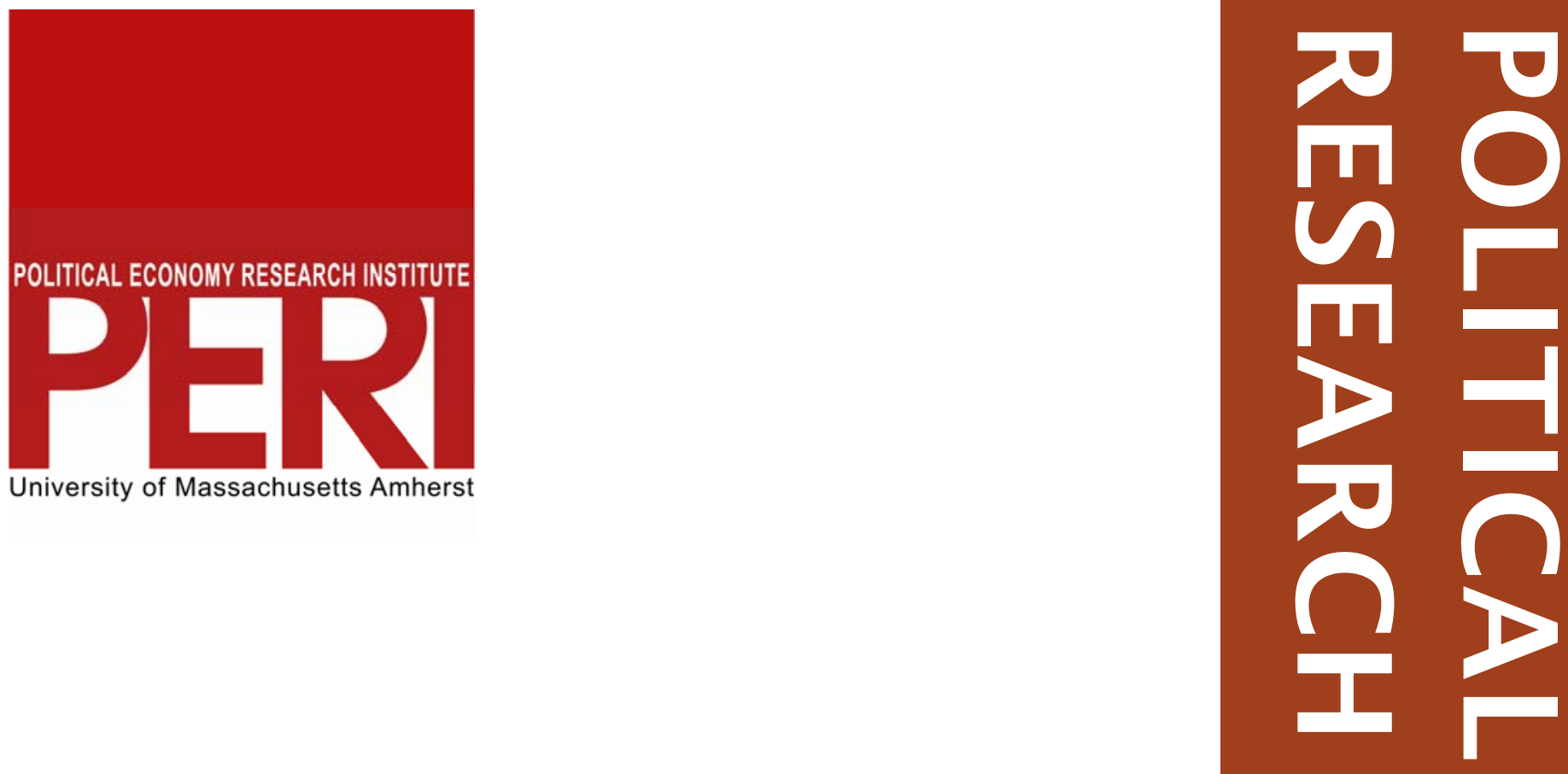

\title{
Is Inequality Bad for the Environment?
}

\author{
James K. Boyce
}

April 2007

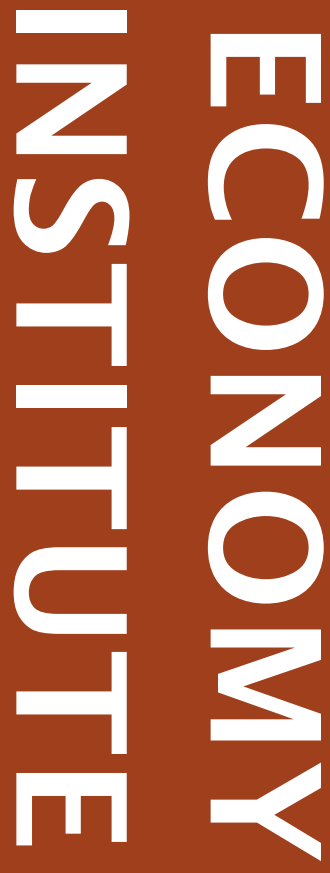

Gordon Hall

418 North Pleasant Street

Amherst, MA 01002

Phone: 413.545 .6355

Fax: 413.577 .0261

peri@econs.umass.edu

www.peri.umass.edu

\section{WORKINGPAPER SERIES}




\title{
Is Inequality Bad for the Environment?
}

James K. Boyce

boyce@econs.umass.edu

April 2007

\begin{abstract}
By respecting nature's limits and investing in nature's wealth, we can protect and enhance the environment's ability to sustain human well-being. But how humans interact with nature is intimately tied to how we interact with each other. Those who are relatively powerful and wealthy typically gain disproportionate benefits from the economic activities that degrade the environment, while those who are relatively powerless and poor typically bear disproportionate costs. All else equal, wider political and economic inequalities tend to result in higher levels of environmental harm. For this reason, efforts to safeguard the natural environment must go hand-in-hand with efforts to achieve more equitable distributions of power and wealth in human societies.

Globalization - the growing integration of markets and governance worldwide today poses new challenges and new opportunities for both of these goals.
\end{abstract}




\section{Prologue}

In the mid-1970s, I lived in a rural village in northwestern Bangladesh, in one of the poorest parts of a poor country. Bangladesh had just had a famine in which some 200,000 people perished. The famine was caused not by an absolute shortage of rice, the staple food of the population, but rather by a combination of grain hoarding by merchants and government ineptitude and corruption. The village where I lived was located in the most famine-stricken district of the country. ${ }^{1}$

To the eyes of a young American, a striking feature of Bangladeshi village life - apart from the poverty of the people - was the virtual absence of negative environmental impacts from human activities. The villagers farmed rice and jute much as their ancestors had for centuries. Agrochemicals had only begun to appear on the scene, and village farmers used them sparingly, if at all. Across the country, Bangladeshi farmers grew some 10,000 different varieties of rice adapted to microclimatic variations in rainfall, flood depths, temperature, and soil type, making the country a storehouse for genetic diversity of humankind's most important food crop. Hundreds of fish species - more than in all Europe - lived in the country's rivers, ponds, and rice paddies, supplying most of the animal protein in the Bangladeshi diet.

There was no trash-collection service in the village, and no need for one, for the villagers produced little, if any, solid waste. Practically everything they consumed - food, cooking fuel, housing materials, herbal medicines - was harvested from their local environment. Crop residues and manures were returned to the earth or burned as fuel. Metal items were carefully recycled, tin containers fashioned into building supplies. Few villagers had ever seen plastic: local children amused themselves by repeatedly dropping a red plastic cup I had brought with me to the village, showing their friends that it didn't break. Despite their poverty - in some ways, because of it - they did not harm the environment, on which their livelihoods depended.

One time, while visiting Dhaka, Bangladesh's capital city, I stumbled upon what may have been as the country's first environmental campaign. The government - a one-party state headed by a once-popular politician who recently had declared himself "president for life" - had just announced a campaign of "urban beautification." Dhaka's sprawling slums, which had multiplied during the famine as starving people from the countryside migrated to the city in search of work or relief, were razed to the ground. Their inhabitants were brusquely herded onto trucks that deposited them outside town, far from the eyes and consciousness of the city's middle and upper-class residents.

The human costs of this policy were vividly brought home to me by a scene I witnessed in front of Dhaka's general post office. An emaciated woman and her baby were sitting on a dirty cloth spread on the sidewalk. Passers-by occasionally dropped a coin. When I emerged from the post office a few minutes later, the woman was gone, perhaps trailing after a well-to-do stranger to plead for alms. Then a police truck drove by, its bed full of destitute people being relocated. Spying the baby, the truck pulled stopped and a policeman dismounted. He unceremoniously tossed her into the back of the truck, which 
lumbered off in search of more human cargo. I do not know whether they picked up the mother.

The irony was inescapable and terrible: In a land where they lived lightly on the earth, the poor themselves were regarded as pollution.

\section{What Is Environmental Harm?}

What does it mean to say something is "bad for the environment" or "good for the environment"? These value judgments rest, implicitly or explicitly, on ethical criteria by which we distinguish better from worse.

A criterion that has gained many adherents in the past two decades is "sustainable development.” This was defined by the World Commission on Environment and Development in its 1987 manifesto, Our Common Future (also known as the Brundtland Report, after commission chair Gro Brundtland), as development that "meets the needs of the present without compromising the ability of future generations to meet their own needs." By this criterion, "environmental harm" means actions that compromise the ability of future generations to meet their needs. Conversely, "environmental improvements" would refer to actions that enhance the ability of future generations to meet their needs.

The Brundtland criterion has the merits of affirming the importance of human well-being and our responsibility to future generations. But as Nobel Prize-winning economist Amartya Sen (2004) has remarked, "Seeing people in terms of only their needs may give us a rather meagre view of humanity." Sen suggests that the ethical basis for value judgments about the environment can be deepened by embracing a broader range of human values. For example, people may believe that we have a responsibility to safeguard the existence of other species (as an illustration, Sen mentions the spotted owl of the Pacific northwest) regardless of whether the species in question serves any practical human needs. In other words, people may value nature for intrinsic as well as instrumental reasons. If so, environmental quality can be seen as an end in itself, and not merely a means to other ends.

Sen also observes that people hold multiple values, and that these cannot be readily reduced to a summary measure such as overall fulfillment of human needs. For example, we may believe that future generations have the right to breathe clean air, and that infringement of this right cannot be adequately compensated by improvements in other dimensions of well-being. Not everything of value can be calibrated on a single scale.

This broader ethical framework - in which "we think of human beings as agents, rather than merely as patients," in Sen's words - implies a central role for citizenship in addressing environmental challenges. Freedom to make value judgments about environmental change, and rights to a clean and safe environment, are themselves important ethical objectives. This is not only a matter of moral vision, but also of 
practical politics. The extent to which people are able to act as citizens depends on how power is structured and distributed in society.

In this essay, I will use the term "environmental harm” to mean impacts on the natural environment that reduce human well-being, with the latter understood to extend beyond needs to the wider canvas of values and rights. To say that actions are bad (or good) for the environment is to say that they are bad (or good) for humankind.

This ethical stance makes no pretense of impartiality: it is unabashedly human-centered. I do not regard homo sapiens as just another species, whose well-being is of no greater consequence than that of any other. In many cases, what is good for other species is good for humans, too. But not always. Sanitation and clean water-supply systems, for instance, improve human well-being by killing bacteria and other pathogens. I regard this as a good thing, an environmental improvement. The eradication of smallpox - the deliberate extinction of a virus species - counts as a good thing, too. This stance does not imply a willful disregard for nature, nor indifference to the fates of other species. On the contrary, an environmental ethics grounded in human well-being recognizes that we are a part of nature, not apart from it.

\section{Three Questions}

Whenever we analyze economic activities that generate environmental harm, we can pose three very basic questions:

- Who benefits from the economic activities that cause the harm? If no one benefits - or at least thinks they do - they would not occur.

- Who suffers environmental harm? If no one is hurt by these activities, they are not a problem - at least, not in terms of human well-being.

- Why is the first group able to impose environmental harm on the second? That is, what allows some people to benefit at the expense of others?

The last of these questions is crucial to understanding the reasons for environmental harm. There are three possible answers to it.

One possibility is that those who are harmed belong to future generations, who are not here to defend themselves. In this case, the only remedy is to cultivate an ethic of intergenerational responsibility, one founded on a moral commitment to safeguard the wellbeing of our children and generations to come.

The second possibility is that those who are harmed lack information. They may know that their children are falling ill, for example, but not know what environmental circumstances are making them sick or who is responsible for them. In this case, the solution lies in greater access to information: environmental education in general and 
right-to-know laws in particular. In the United States, for example, the Emergency Planning and Community Right-to-Know Act of 1986, passed in the wake of the chemical plant disaster in Bhopal, India, created the Toxics Release Inventory which makes information on releases of toxic chemicals by industrial facilities available to the public.

The final possibility is that those who are harmed are alive today and well aware of the costs imposed on them, but lack the power to prevail in making social decisions about the environment. In this case, the solution lies in redistributing power, so that those who suffer environmental harm are better able to defend themselves - and the environment from others who benefit from activities that cause the problem.

\section{Purchasing Power and Political Power}

Human beings are socially differentiated in terms of wealth and influence. Differences in wealth translate into differences in purchasing power. Differences in influence translate into differences in political power.

In this respect humans are different from other species. Consider, for example, pondweed, a plant species sometimes used by ecologists to illustrate the perils of exponential growth. ${ }^{2}$ Assume that the weed doubles in volume every day, and that in 30 days it will fill the pond completely, making further growth impossible and perhaps overwhelming ecological balances vital to the continued existence of the pondweed itself. When, the ecologist asks, is the pond half full? The answer, of course, is the $29^{\text {th }}$ day. This parable is invoked to depict human pressure on the carrying capacity of planet Earth: metaphorically speaking, we are nearing the end of the month.

Each pondweed organism is pretty much like any other. But humans differ greatly from one another, both in their impacts on the environment and in their ability to shield themselves from these impacts. The pondweed analogy deflects attention from these differences, and from how they affect our interactions with nature.

To understand how inequalities among humans contribute to environmental harm, we need to look more closely at two forms of power: purchasing power and political power.

\section{Purchasing power}

In a market economy, people vote on what to produce in proportion to the money they spend. Economists call this "effective demand." This differs from simple desire or need. A person can be hungry, and in that sense have demand for food, but she doesn't have effective demand - the ability to vote in the marketplace - unless hunger in her stomach is backed up by money in her pocket. The distribution of purchasing power determines how much of society's resources will be devoted to producing rice and beans, and how much to producing champagne and luxury automobiles. 
Purchasing power plays a central role in describing what happens in markets. In costbenefit analysis, it also plays a central role in prescribing what should happen if and when the government intervenes to correct "market failures" that arise in cases of public goods, like highways, schools, and national defense, and in cases of externalities, like pollution, that affect people who are not party to the market exchange between buyer and seller.

When the government promulgates regulations to curtail pollution, for example, it must confront the practical question: how much pollution is too much? It would be nice to live in a world with no pollution whatsoever, but, as economists are quick to point out, cutting pollution has costs as well as benefits. People need and want to eat, wear clothes, use medicines, move about, and so on, and producing these goods and services often produces some pollution, too. Faced with the choice between more goods and services and less pollution, and informed by the principle of diminishing returns (the more we have of anything, the less each additional increment is worth), the economist tells the government to aim for the "optimal level of pollution," defined as the point at which society's benefit from additional pollution reduction equals its cost in terms of foregone consumption of other goods and services.

The phrase "optimal level of pollution" rankles many environmentalists, but it is hard to argue with the logical proposition that the costs and benefits of any course of action ought to be weighed against each other. The problem is how to measure all the relevant costs and benefits. The economist has a toolkit for this purpose: cost-benefit analysis. It translates all costs and benefits into a single unit of measurement, money. Economists have devised ingenious ways to translate non-market values - such as the value of cleaner air or the existence of the spotted owl - into monetary terms. Contingent valuation surveys, for example, are used to ask people how much they would be willing to spend for environmental quality - say, to protect an endangered species. Hedonic regression analysis, another popular technique, used actual market data to infer implicit prices; for example, by analyzing how housing prices vary with distance from an airport (controlling for other variables like the size of the house), in order to measure the cost of noise pollution.

The foundation for the valuation techniques of cost-benefit analysis is willingness to pay. The costs of environmental harms are measured by how much people are willing to pay to avoid them. This is how demand for goods and services is measured in the marketplace, so there is a certain consistency in using the same criterion to measure demand for environmental quality, and to use the results in making public policy. The willingness-to-pay criterion for valuation means, however, that the needs and desires of some people count more than the needs and desires of others - not necessarily because their desire for clean air or water is any stronger, but because they wield more purchasing power to back up their preferences.

Behind differences in willingness to pay lie differences in ability to pay. If my willingness to pay for gold mined near your community is high, and your community's ability (and hence willingness) to pay to protect its air and water from pollution by 
mining operations is low, then by the logic of the cost-benefit analyst I should get the gold and you should get the pollution. In this way, differences in purchasing power can affect not only decisions made by private parties in response to market signals, but also public-policy decisions made by governments.

\section{Political power}

In practice, real-world political systems do not faithfully adhere to the prescriptions of cost-benefit analysts. Individuals, groups, and classes differ from each other not only in their purchasing power but also in their political power. The latter includes differences in their ability influence social decisions on environmental policies. As a result, some costs and benefits may count more than others.

Political power takes various forms:

- decision power to prevail in contests to determine what decision-makers, both public and private, will or will not do;

- agenda power to keep questions off (or on) the table of the decision makers;

- value power to shape others' preferences of to coincide with one's own; and

- event power to alter the circumstances that others face - for example, by blowing smoke into the atmosphere - thus presenting them with a fait accompli.

Each of these forms of power can lead to decisions that diverge from the optimum prescribed by cost-benefit analysis. ${ }^{3}$

If political power were distributed equally across the population, and social decisions were based simply on cost-benefit calculations, then purchasing power would be the only dimension of human differentiation that matters for environmental decisions. Once we recognize, however, that political power in practice is unequally distributed, and that it tends to be correlated with purchasing power - that is, wealth and political influence generally go together - then both dimensions of social differentiation matter, and reinforce each other.

\section{The Environmental Impact of Inequality: Two Hypotheses}

Two hypotheses can be advanced about the environmental impact of inequalities in the distribution of purchasing power and political power:

- First, environmental harm is not randomly distributed across the population, but instead the distribution of wealth and power. The relatively wealthy and powerful tend to benefit disproportionately from the economic activities that generate environmental harm. The relatively poor and powerless tend to bear a disproportionate share of the environmental costs.

- Second, the total magnitude of environmental harm depends on the extent of inequality. Societies with wider inequalities of wealth and power will tend to have 
more environmental harm. Conversely, societies with relatively modest degrees of economic and political disparities will tend to have less environmental harm.

\section{Environmental injustice}

The first hypothesis operates on both the benefit side and the cost side of the coin. Benefits from economic activities that inflict environmental harm accrue to consumers insofar as the savings from cost externalization (for example, releasing toxic chemicals out the smokestack rather than spending money on pollution control) are passed to them in the form of lower prices. Benefits accrue to the owners of firms insofar as they are able to capture these savings in the form of higher profits. On the consumer side, the rich generally get a bigger share of the benefits, for the simple reason that they consume more than the poor. On the producer side, again they get a bigger share of the benefits, since they own more productive assets, including corporate stocks. For these reasons, no matter what the division of gains between consumers and firms, the rich reap the largest share. Even if the costs of environmental harm were equally shared by all - for example, if everyone breathes the same polluted air and drinks the same polluted water - this would skew the net benefits from environmentally harmful economic activities in favor of the wealthy.

In practice, many environmental costs are localized, rather than being uniformly distributed across space. This makes it possible for those who are relatively wealthy and powerful to distance themselves from environmental harm caused by economic activities (Princen 1997). Within a metropolitan area, for example, the wealthy can afford to live in neighborhoods with cleaner air and more environmental amenities. Furthermore, sometimes there are private substitutes for public environmental quality. In urban India, for instance, where public water supplies are often contaminated, the upper and middle classes can afford to consume bottled water. The poor cannot. In such cases, because access to private substitutes is based on ability to pay, again the rich are better able to avoid environmental harm.

A substantial literature on environmental justice in the United States has documented the fact that low-income people and communities of color (that is, communities with aboveaverage percentages of non-white and non-Anglo residents) often bear disproportionate environmental harms. ${ }^{4}$ These findings are consistent with the first hypothesis. A number of these studies have found that race and ethnicity matter, even when controlling for income: communities with higher percentages of African-Americans, Latinos, AsianAmericans, and Native Americans tend to face greater environmental hazards. ${ }^{5}$ This finding suggests that political power (correlated with race and ethnicity in the United States) has an impact on exposure to environmental harm, above and beyond whatever can be explained simply by differences in purchasing power.

Even in cases of environmental harm from which there is no escape - widely dispersed pollutants and global climate change are examples - those who are relatively poor and powerless tend to be most vulnerable. Living closest to the margin of survival, they have least ability to withstand adversity. They have less ability to afford remedial measures, 
like health care. And they have less political clout to secure remedial actions from government authorities. Similar vulnerability disparities are revealed by natural disasters, as when Hurricane Katrina hit New Orleans in August 2005. "In a sense, environmental justice is about slow-motion disasters," in the words of a recent study of Katrina's impact, "and disasters reveal environmental injustice in a fast-forward mode" (Pastor et al. 2006, p. 9).

\section{More inequality, more harm?}

The second hypothesis - that more inequality causes more environmental harm overall may be less intuitively evident than the first. Inequalities of wealth and power could have two opposing effects. When the beneficiaries from environmentally harmful activities are more powerful than those who bear their costs, greater inequality can be expected to result in more environmental harm. On the other hand, when those who bear the costs are more powerful than the beneficiaries, we might expect the opposite: greater inequality yields less environmental harm.

Which scenario is more common? The second one certainly occurs, for example when African tribespeople are expelled from their traditional hunting grounds to create protected areas for foreign tourists, a phenomenon that has been labeled "coercive conservation." ${ }^{6}$ The slum clearance program in Bangladesh described in the prologue is another example. But there are goods reasons to believe that the first scenario is far more prevalent. If, as I have argued above, the benefits of environmentally harmful activities flow disproportionately to the relatively well-off by virtue of their higher consumption and capital ownership, and purchasing power is correlated with political power, it follows that the beneficiaries of these activities tend to be more powerful than those who bear net costs - in which case, wider inequalities can be expected to translate into greater environmental harm.

In a statistical test of the second hypothesis, Boyce et al. (1999) found that among the 50 U.S. states, those with more equitable distributions of power (measured by voter participation, educational attainments, tax fairness and Medicaid access) tend to have stronger environmental policies and better environmental outcomes. Further evidence in support of this hypothesis comes from a study of the relationship between residential segregation and cancer risks from air pollution in the United States, which found that greater segregation on racial and ethnic lines is correlated with worse environmental and health outcomes for all groups, not only for people of color (Morello-Frosch and Jesdale 2006).

Similarly, cross-country studies at the international level have found that a more equitable distribution of power - measured by such variables as democracy, political and civil rights, and adult literacy - is correlated with better environmental quality, even while controlling for other variables such as differences in per capita income. ${ }^{7}$ 
In sum, both theoretical reasoning and empirical evidence support the conclusion that inequality is bad for the environment. People are not like pondweed. How we treat the natural environment depends on how we treat each other.

\section{Room for Hope}

There is another important way that humans differ from pondweed: we have brains. Indeed we are exceptional among all species in our ability to accumulate knowledge, pass it from one generation to the next, and change our behavior accordingly. This includes knowledge about our interactions with the natural environment and with each other.

\section{Respecting nature’s limits}

We can learn how to respect nature's limits, and thus how to limit environmental harm if we choose to do so. We can learn about the growth rates of renewable natural resources, such as trees in forest and fish in the sea, and we can manage our own harvests of these resources to ensure sustainable yields. We can learn about nature's finite stocks of non-renewable resources, such as minerals and fossil fuels, and we can develop recycling and renewable alternatives to avert future shortages. We can learn about the limited capacity of air, lands, and water bodies to safely absorb and break down wastes, and we can limit the rates at which we discharge pollutants accordingly.

As an illustration, consider our response to the threat posed by chemicals that were depleting the Earth's protective ozone layer, exposing life on the planet to increasing levels of ultraviolet-B radiation. The danger was not recognized until the early 1970s, when scientists first hypothesized that chlorofluorocarbons (CFCs), man-made compounds used for a variety of purposes, including aerosol propellants and air conditioner coolants, were breaking down ozone molecules in the Earth's stratosphere. The harm was invisible but insidious. In a remarkable instance of international cooperation, by 1987 the nations of the world had agreed to curtail their CFC emissions via the Montreal Protocol. ${ }^{8}$ No other species is capable of such conscious self-regulating behavior.

Of course, to say that we can modify our actions on the basis of knowledge about nature's limits does not mean that we necessarily will do so. But if we choose to act, we can. And, as the Montreal Protocol illustrates, sometimes we do. The question is, why do we act to protect the environment in some times and places, and not in others? The answer, I believe, is that whether and how we act (or fail to act) depends on the balance of power in the present generation between those who benefit by ignoring nature's limits and those who pay the price, and on whether we embrace an ethic of responsibility toward future generations.

Nor do I wish to imply that humans are omniscient, understanding fully the consequences of our actions. Had scientists been a few decades slower to grasp the environmental implications of CFC emissions, we might not have recognized the threat until it was too 
late. We need to understand not only nature's limits, but also the limits of our own knowledge. Given the uncertainties and unknowns about the environmental impacts of our actions, prudence demands that we adopt a "precautionary" approach to environmental policy. ${ }^{9}$

Investing in nature's wealth

Humans can not only deplete nature's wealth; we also can increase it. If our value system is founded on long-term human well-being - if this is the basis on which we compare states of the world, and define what is good and bad for the environment - then we can improve the environment as well as harm it.

There are three ways that humans invest in nature's wealth:

- Ecological restoration repairs past harms. Examples include the reforestation of deforested landscapes; the replenishment of depleted fisheries; the clean-up of contaminated soils and water bodies; and the restoration of degraded wildlife habitat. $^{10}$

- Co-evolution refers to human modifications that create an environment that is better able to support long-term human well-being. One example is "soil banking": farming practices that build deeper and more fertile soils, such as terra preta do indio ('dark earth of the Indians') in Amazonia and those of the acequia landscape mosaic in the upper Rio Grande bioregion of the southwestern United States. ${ }^{11}$ Another example - arguably the most valuable investment in nature's wealth in human history - is the domestication of plants and animals that began some 10,000 years ago, and the subsequent evolution of genetic diversity in crops and livestock. ${ }^{12}$

- Environmental preventive health refers to measures to reduce the prevalence of pathogens and disease-bearing insects. One example, already mentioned, is the eradication of the smallpox virus in international effort that culminated in the mid-1970s. Another example is the modification of aquatic habitats to reduce mosquito populations, a form of investment that played a major role in eliminating malaria from Europe and North America. ${ }^{13}$

In all three ways, human beings can and sometimes do improve the environment, from the standpoint of long-term human well-being. Humans are not necessarily a blight on the face of the planet, a cancer that ultimately will destroy its host. We have learned a great deal about how to respect nature's limits and invest in nature's wealth, and we have the capacity to learn more. In our dealings with nature, there is room for hope. 


\section{Making social change}

The inequalities of power and wealth that generate environmental harm are not forces of nature. Political and economic disparities are social constructions, and as such they can be reconstructed.

To be sure, there is no certainty that social change will proceed inexorably toward more democratic distributions of political power and more egalitarian distributions of purchasing power. It is all too easy to find past and present examples of movements in the opposite direction. But to say that something is not inevitable is not to say that it is impossible.

In fact, an even stronger claim is possible: there is ample evidence that the overall trend in human history, notwithstanding periodic reversals, is toward more equality in our social arrangements. Only three centuries ago, monarchs and aristocracies ruled most of the world. A century and a half ago, slavery was still legal in much of the United States. The state of Massachusetts, the first in the country to mandate free primary education for all children, did so only in 1852; it was not until 1918 that all states had followed suit. The amendment to the U.S. constitution that granted women the right to vote was adopted less than a century ago. In much of Asia and Africa, colonial rule ended only two generations ago. It has been little more than a decade since apartheid ended in South Africa. "The arc of the moral universe is long," Dr. Martin Luther King remarked in his 1965 commencement address at Oberlin College, "but it bends toward justice."

There is room for home in our dealings with each other, too.

\section{One World, Ready or Not}

Both the prospects and need for changes in our relationships with nature and each other are affected by changes in the scale at which human interactions occur. For much of human history, the implications of the fact that we share a single planet were hidden from view by spatial fragmentation. This slowly changed over time, especially with the development of agriculture, states, and more effective means of transport beginning some ten millennia ago. The pace of change accelerated in the past few centuries, in the process nowadays dubbed "globalization." Today the fact that we live in one world is not only a physical reality, but also an economic, cultural, and political reality.

\section{Uneven globalization: Markets and governance}

Globalization has proceeded most rapidly in the economic arena. Around the world, production and consumption are being increasingly integrated into a single market. Indeed, for many the term "globalization" has come to signify not only the process of economic integration, but also the subordination of more and more economic activity across the globe to the laws of the market. The extension of the market brings tangible benefits, as Adam Smith famously observed in The Wealth of Nations: responding to 
price signals, decentralized producers are guided by an "invisible hand" to specialize in what they can make most cheaply, unleashing impressive productivity gains.

But the market also has important limitations:

- Market failure: One way to make goods cheaply is to push costs onto others generating what economists call "negative externalities.” For example, firms that do not spend money on pollution control may enjoy a competitive advantage over first that do. As markets extend their reach, the costs of such market failures can grow alongside the benefits of specialization.

- Fairness: The production and distribution of goods and services for the market are driven by effective demand - that is, willingness to pay backed by ability to pay. An inequitable distribution of purchasing power leads to an inequitable distribution of resources.

- Resilience: The market pursues a logic of short-term optimization: lowest-cost producers using the "best" technology can undersell rivals and ultimately drive them out of business. As a result, producers tend to converge on the same technology. Yet resilience - the ability to withstand shocks and adapt to changing circumstances - requires a range of alternative technological options. ${ }^{14}$

- Moral capital: Finally, by elevating a narrowly conceived "self-interest” above all other values, markets may lead to depreciation of moral capital that is crucial to the functioning of society. In fact, widespread commitment to moral precepts is necessary for markets themselves to function, since respect for rights and contractual obligations typically rests not on self-interest but instead on accepted norms about what is the right thing to do. ${ }^{15}$

For all four reasons, the globalization of markets needs to be complemented by the globalization of governance. The latter includes not only formal international institutions and inter-governmental agreements but also informal governance by non-state institutions and networks. Many of the problems associated with globalization arise from the fact that it has been uneven: the development of global governance has lagged behind the development of global markets. ${ }^{16}$

\section{NAFTA and the environment: A case study in uneven globalization}

The environmental consequences of uneven globalization process can be illustrated by looking at the effects of the North American Free Trade Agreement (NAFTA), the free trade agreement among the U.S., Mexico and Canada that went into effect in 1994. In the early 1990s, the debate over NAFTA split the U.S. environmental movement. Some maintained that the trade agreement would promote "harmonization upwards," a continental convergence to higher environmental standards, by generating higher incomes and stronger demand for environmental protection in Mexico. Others contended that it would spark a "race to the bottom," as firms moved (or threatened to move) south of the U.S.-Mexico border to take advantage of lax environmental regulations. 
Both sides in the debate shared one premise: environmental practices in Mexico were evidently inferior to those in the U.S. and Canada. This assumption helps to explain why few environmentalists voiced concern about what in the end may turn out to be NAFTA's most profound environmental impact: the erosion of Mexico's rich heritage of genetically diverse maize varieties by cheap corn imported from the U.S.

Maize ('corn' in U.S. parlance) is the single most important crop in both countries. ${ }^{17}$ On the eve of NAFTA, U.S. maize sold at roughly $\$ 110$ per ton at the border, whereas Mexican growers were receiving $\$ 240$ per ton for their crops. With the dismantling of trade barriers, the Mexican price is now converging to the lower U.S. price, hitting hard at the livelihoods of Mexican campesinos. ${ }^{18}$

By the measuring stick of market prices, U.S. farmers are more efficient than Mexican growers. But this competitive edge results, in no small measure, from the neglect of market failures on both sides of the border. ${ }^{19}$ U.S. corn production relies on massive applications of pesticides, fertilizers, and energy inputs, all of which generate substantial environmental harm. The resulting costs do not figure in the market price.

At the same time, the campesino farmers of southern and central Mexico today provide a great "positive externality" to humankind by sustaining genetic diversity in one of the world's most important food crops. In their small plots, where corn was first domesticated some seven millennia ago, the maize plant continues to evolve via the process Darwin called "artificial selection," as farmers select seeds for the following year's crop that from the plants that perform best in the face of changing conditions. Mexican farmers still grow thousands of varieties of maize. In the United States, by contrast, fewer than a dozen varieties now account for half of the country's total corn acreage.

As a result of its low diversity, the US corn crop has a high degree of genetic vulnerability the eggs-in-one-basket syndrome - a problem dramatically revealed in 1970 when a new strain of leaf blight destroyed one-fifth of the nation's harvest. In the effort to stay ahead of the insects and plant diseases that evolve rapidly in genetically uniform fields, U.S. plant breeders engage in a "varietal relay race," constantly seeking to develop new resistant varieties. The average commercial lifespan of a corn variety in the U.S. is only seven years, after which it is replaced by new ones. In effect, modern agriculture substitutes diversity through time for diversity at any point in time. The raw material that plant breeders use in this relay race is the genetic diversity that has been bequeathed to us by generations of small farmers in Mexico and elsewhere. ${ }^{20}$

The irony is that under NAFTA, the success of U.S. corn production in the marketplace is undermining the genetic base on which its own long-term viability depends. The globalization of the market is being accompanied by the globalization of market failure, and a loss of resilience. In the short term, the main people harmed by this process are the Mexican campesinos, who lack the political power to ensure that their investments in nature's wealth are rewarded. In the long term, those harmed are future generations around the world, whose food security is being undermined by the erosion of crop genetic diversity. 
Remedying this environmental harm will require more than defensive actions by single individuals, communities, or states, important though these may be. Ultimately this and other transnational environmental problems require building institutions that bridge the gap between the globalization of markets and the globalization of governance. ${ }^{21}$

\section{Concluding Remarks}

In this essay, I have explored some of the implications of recognizing that environmental harm is not a random by-product of economic activities, but instead a cost that is imposed on some and that benefits others. Rectifying the market failures and governance failures that lead to environmental harm requires repairing the disparities of wealth and power that enable these failures.

This does not mean that greater equality is a panacea for all environmental ills. A more democratic distribution of power and a more egalitarian distribution of wealth are not all that is needed to prevent environmental harm. To say that these are necessary does imply that they are sufficient. Safeguarding the natural environment also will require us to cultivate an ethic of moral responsibility to others - particularly when the costs of environmental harm would primarily fall upon future generations.

We can have a healthy environment, and bequeath one to future generations, by respecting nature's limits and investing in nature's wealth. Achieving these goals does not only require rebalancing our relationships with nature. It will also require rebalancing our relationships with our fellow humans. 


\section{Notes}

${ }^{1}$ For accounts of the famine and its causes, see Sen (1981) and Ravallion (1987). For an account of the life in the village, see Hartmann and Boyce $(1979,1983)$.

${ }^{2}$ See, for example, Brown (1978).

${ }^{3}$ For discussion, see Bartlett (1989) and Boyce (2002).

${ }^{4}$ For reviews, see Szasz and Meuser (1997), Bullard (2000), Pastor (2003), and Boyce (2006a).

${ }^{5}$ See, for example, Bouwes et al. (2003) and Ash and Fetter (2004).

${ }^{6}$ See, for example, Peluso (1993), Neumann (2001), and Mulder and Coppolillo (2005, pp. 31-37).

${ }^{7}$ See, for example, Torras and Boyce (1998) and Barrett and Graddy (2000). For a review of these and other studies, see also Boyce (2006).

${ }^{8}$ For an account, see Haas (1992).

${ }^{9}$ For discussion, see Harremoës et al. (2002) and Dorman (2005).

${ }^{10}$ For examples, see Narain and Agarwal (2007) on water harvesting in semi-arid zones of rural India, and Rahman and Minkin (2007) on the rehabilitation of inland fisheries in Bangladesh. A distinction is sometimes made between restoration and rehabilitation, with the former referring to returning an ecosystem to "its historic trajectory" and the latter to "the reparation of ecosystem processes, productivity and services” (Society for Ecological Restoration 2004). If humans are regarded as an alien species - if we are truly apart from nature, not a part of it - this distinction makes sense: one may imagine the "historic trajectory" of ecosystems in the absence of any human impacts whatsoever. In my view, this is a peculiar view of history. In any event, proponents of this distinction have concluded that restoration "probably encompasses a large majority of project work that has previously been identified as rehabilitation.”

${ }^{11}$ See, respectively, Mann (2002) and Peña (2003). For more examples of soil banking, see Brookfield (2001, pp. 96-97).

${ }^{12}$ For discussion, see Boyce (2006b).

${ }^{13}$ For discussion, see Kitron and Spielman (1989) and Willott (2004).

${ }^{14}$ For discussion, see Rammel and van den Bergh (2003).

${ }^{15}$ For discussion, see Basu (1983), Sen (1986), and Bell (1996).

${ }^{16}$ For discussion, see Young (1994) and Boyce (2004).

${ }^{17}$ Michael Pollan (2006, pp. 22-23) observes that once the cycling of corn through animals is counted, the average American today has more corn in his diet than the average Mexican.

${ }^{18}$ For further discussion, see Boyce (1996, 2004). So far, the sharp decline in Mexican corn production that was predicted by many as a result of NAFTA has not occurred, apparently because economic opportunities elsewhere in the Mexican economy have been so scarce (see Ackerman et al. 2003).

${ }^{19}$ Government subsidies and natural advantages (such as more regular rainfall in the U.S. corn belt) also play a role. For further discussion, see Boyce (1996). 
${ }^{20}$ Samples of many Mexican maize varieties are stored in "seed banks” at agricultural research institutes. But seed banks are insecure, being subject to the perennial hazards of inadequate funding, accidents, and war. Moreover, having seeds in the bank is not the same as knowing about varietal properties such as pest resistance and climate sensitivity, information that is most readily obtained in the field. And even at best, seed banks can conserve only the existing stock of genetic diversity; they cannot replicate the ongoing process of evolution that takes place in the farmers' fields. For further discussion of the value of in situ (in-the-field) crop genetic diversity, see Brush (2003) and Boyce (2006b).

${ }^{21}$ For discussion of formal and informal institutions that could help to conserve crop genetic diversity, see Mann (2004) and Boyce (2006b). 


\section{References}

Ackerman, Frank, Timothy A. Wise, Kevin P. Gallagher, Luke Ney, and Regina Flores (2003), 'Free Trade, Corn, and the Environment: Environmental Impacts of US-Mexico Corn Trade Under NAFTA,’ Medford, Massachusetts: Tufts University, Global Development and Environment Institute, Working Paper No. 03-06.

Ash, Michael and T. Robert Fetter (2004) 'Who Lives on the Wrong Side of the Environmental Tracks?’ Social Science Quarterly 85(2): 441-462.

Barrett, Scott and Kathryn Graddy (2000) 'Freedom, Growth, and the Environment.' Environment and Development Economics 5: 433-456.

Bartlett, Randall (1989) Economics and Power: An Inquiry into Human Relations and Markets. Cambridge: Cambridge University Press.

Basu, Kaushik (1983) 'On Why We Do Not Try to Walk Off Without Paying after a Taxi Ride,’ Economic and Political Weekly 18: 2011-12.

Bell, Daniel (1996) The Cultural Contradictions of Capitalism. $2^{\text {nd }}$ edn. New York: Basic Books.

Bouwes, Nicolaas et al. (2003) 'Information for Empowerment: The EPA's RiskScreening Environmental Indicators Project,’ in James K. Boyce and Barry G. Shelley, eds., Natural Assets: Democratizing Environmental Ownership. Washington, DC: Island Press, ch. 6.

Boyce, James K. (1996) 'Ecological Distribution, Agricultural Trade Liberalization, and In Situ Genetic Diversity,’ Journal of Income Distribution 6(2): 263-284.

Boyce, James K. (2002) The Political Economy of the Environment. Northampton: Edward Elgar.

Boyce, James K. (2004) 'Green and Brown? Globalization and the Environment,' Oxford Review of Economic Policy 20(1): 105-128.

Boyce, James K. (2006a) 'Inequality and Environmental Protection,' in Jean-Marie Baland, Pranab Bardhan, and Samuel Bowles, eds., Inequality, Collective Action, and Environmental Sustainability. Princeton: Princeton University Press, pp. 314-348.

Boyce, James K. (2006b) 'A Future for Small Farms? Biodiversity and Sustainable Agriculture,' in James K. Boyce, Stephen Cullenberg, Prasanta K. Pattanaik and Robert Pollin, eds., Human Development in the Era of Globalization: Essays in Honor of Keith B. Griffin. Northampton: Edward Elgar, pp. 83-104. 
Boyce, James K., Andrew R. Klemer, Paul H. Templet, and Cleve E. Willis (1999) "Power Distribution, the Environment, and Public Health: A State-level Analysis." Ecological Economics 29: 127-140. Reprinted in Boyce (2002, ch. 6).

Brookfield, Harold (2001) Exploring Agrodiversity. New York: Columbia University Press.

Brown, Lester (1978) The Twenty-Ninth Day: Accommodating Human Needs and Numbers to the Earth's Resources. New York: Norton.

Brush, Stephen B. (2003) 'The Lighthouse and the Potato: Internalizing the Value of Crop Genetic Diversity,’ in James K. Boyce and Barry G. Shelley, eds., Natural Assets:

Democratizing Environmental Ownership. Washington, D.C.: Island Press, ch. 10.

Bullard, Robert D. and Glenn S. Johnson (2000) 'Environmental Justice: Grassroots Activism and Its Impact on Public Policy Decision Making,' Journal of Social Issues 56(3): 555-578.

Dorman, Peter (2005) ‘Evolving Knowledge and the Precautionary Principle,’ Ecological Economics, 53: 169-176.

Haas, Peter (1992) 'Banning Chlorofluorocarbons: Epistemic Community Efforts to Protect Stratospheric Ozone,’ International Organization 46(1): 187-224.

Harremoës, Poul et al. (2002) The Precautionary Principle in the $20^{\text {th }}$ Century: Late Lessons from Early Warnings. London: Earthscan, for the European Environment Agency.

Hartmann, Betsy and James K. Boyce (1979) Needless Hunger: Voices from a Bangladesh Village. San Francisco: Institute for Food and Development Policy.

Hartmann, Betsy and James K. Boyce (1983) A Quiet Violence: View from a Bangladesh Village. London: Zed Press, and San Francisco: Institute for Food and Development Policy.

King, Martin Luther (1965) "Staying Awake through a Great Revolution," commencement address at Oberlin College, Oberlin, Ohio, June.

Kitron, Uriel and Andrew Spielman (1989) 'Suppression of Transmission of Malaria Through Source Reduction: Antianopheline Measures Applied in Israel, the United States, and Italy,' Reviews of Infectious Diseases 11(3): 391-406.

Mann, Charles (2002) ‘The Real Dirt on Rainforest Fertility,’ Science 297: 920-923.

Mann, Charles (2004) Diversity on the Farm. New York: Ford Foundation, and Amherst, Massachusetts: Political Economy Research Institute. Available at http://www.peri.umass.edu/fileadmin/pdf/Mann.pdf. 
Morello-Frosch, Rachel A., and Bill Jesdale (2006) "Separate and Unequal: Residential Segregation and Estimated Cancer Risks Associated with Ambient Air Toxics in US Metropolitan Areas." Environmental Health Perspectives. 114 (3): 386-393.

Mulder, Monique B. and Peter Coppolillo (2005) Conservation: Linking Ecology, Economics, and Culture. Princeton: Princeton University Press.

Narain, Sunita and Anil Agarwal (2007) 'Harvesting the Rain: Fighting Ecological Poverty through Participatory Democracy,' in James K. Boyce, Sunita Narain and Elizabeth A. Stanton, eds., Reclaiming Nature: Environmental Justice and Ecological Restoration. London and New York: Anthem Press, ch. 3.

Neumann, Roderick P. (2001) 'Disciplining Peasants in Tanzania: From State Violence to Self-Surveillance in Wildlife Conservation,' Michael Watts and Nancy Peluso, eds., Violent Environments, Ithaca, Cornell University Press, ch. 13.

Pastor, Manuel (2003) 'Building Social Capital to Protect Natural Capital: The Quest for Environmental Justice,' in James K. Boyce and Barry G. Shelley, eds., Natural Assets: Democratizing Environmental Ownership. Washington, DC: Island Press, ch. 4.

Pastor, Manuel, Robert D. Bullard, James K. Boyce, Alice Fothergill, Rachel MorelloFrosch, and Beverly Wright (2006) In the Wake of the Storm: Environment, Disaster, and Race after Katrina. New York: Russell Sage Foundation.

Peluso, N. (1993) 'Coercing conservation: The politics of state resource control,' Global Environmental Change 3(2): 199-217.

Peña, Devon (2003) 'The Watershed Commonwealth of the Upper Rio Grande,' in James K. Boyce and Barry G. Shelley, eds., Natural Assets: Democratizing Environmental Ownership. Washington, D.C.: Island Press, ch. 9.

Pollan, Michael (2006) Omnivore's Dilemma: A Natural History of Four Meals. New York: Penguin Press.

Princen, Thomas (1997) 'The Shading and Distancing of Commerce: When Internalization Is Not Enough,’ Ecological Economics 20: 235-253. Reprinted in T. Princen et al., eds., Confronting Consumption, Cambridge, MA: MIT Press, 2002, ch. 5.

Rahman, Mokleshur and Stephen F. Minkin (2007) 'Net Benefits: The Ecological Restoration of Inland Fisheries in Bangladesh,' in James K. Boyce, Sunita Narain and Elizabeth A. Stanton, eds., Reclaiming Nature: Environmental Justice and Ecological Restoration. London and New York: Anthem Press, ch. 4. 
Rammel, Christian and Jeroen C.J.M. van den Bergh (2003) 'Evolutionary Policies for Sustainable Development: Adaptive Flexibility and Risk Minimising,’ Ecological Economics 47: 121-133.

Ravallion, Martin (1987) Markets and Famines. Oxford: Clarendon.

Sen, Amartya (1981) Poverty and Famines: An Essay on Entitlements and Deprivation. Oxford: Clarendon.

Sen, Amartya (1986) ‘Adam Smith’s Prudence,’ in Sanjaya Lall and Frances Stewart, eds., Theory and Reality in Development. London: Macmillan.

Sen, Amartya (2004) 'Why We Should Preserve the Spotted Owl,' London Review of Books 26(3), February 5.

Society for Ecological Restoration (2004) The SER International Primer on Ecological Restoration. Tucson: Society for Ecological Restoration International. Available at www.ser.org.

Szasz, Andrew and Meuser, Michael (1997) 'Environmental Inequalities: Literature Review and Proposals for New Directions in Research and Theory,' Current Sociology, 45(3), 99-120.

Torras, Mariano and James K. Boyce (1998) “Income, Inequality, and Pollution: A Reassessment of the Environmental Kuznets Curve,” Ecological Economics 25: 147-160. Reprinted in Boyce (2002, ch. 5).

Willott, Elizabeth (2004) 'Restoring Nature, Without Mosquitoes?’ Restoration Ecology 12(2): 147-153.

World Commission on Environment and Development (1987) Our Common Future (the Brundtland Report). New York: Oxford University Press.

Young, Oran (1994) International Governance: Protecting the Environment in a Stateless Society. Ithaca: Cornell University Press. 